\title{
The Development and Cultural Studies of Contemporary Pop Music
}

\author{
Jing Liang \\ Weinan Normal University, Weinan, Shaanxi, 714000
}

Keywords: Contemporary Pop Music, Cultural Study, Development Study

\begin{abstract}
This article from the perspective of culture, sociology, reveal the various cultural characteristics of pop music, and on this basis proposed a new definition of pop music concept. In the research method, this chapter chooses to analyze and study the cultural mode formed by the relationship between the development of contemporary pop music and the social and cultural environment in China from the unique perspective of the influence of the cultural environment of contemporary Chinese society on the development and characteristics of pop music. The first proposal was that China's contemporary pop music is a multi-cell cultural complex. The changes and development of the cultural environment of contemporary Chinese society determine the new concept of the stage characteristics of the contemporary pop music in China.
\end{abstract}

\section{Introduction}

In the late 1970s, with the implementation of the policy of reform and opening up, Chinese society entered a new historical period. In the music and cultural life, along with the rapid development of the commodity economy and the influx of overseas home appliances into the mainland, tape recorders and audio-video products began to enter massively into places for the family and public entertainment. For a time, RTHK popped up rapidly. The popular songs of Hong Kong and Taiwan, represented by Teresa Teng, Liu Wen-zheng and Xu Xiaofeng, have entered the Mainland mainly through non-governmental exchanges such as visiting relatives and traveling between mainland China and Hong Kong and Taiwan, and laid the foundation for the development of the audiovisual market in the future. In the early 1980s, Hong Kong and Taiwan pop songs such as The Story of a Small Town, The Moon Represents My Heart, The Olive Tree and The Trail of the Country have been widely circulated in Mainland China. The introduction of popular music in Hong Kong and Taiwan and its widespread dissemination can be said to have rapidly changed the original music culture. It can be said that these Hong Kong-Taiwan singers and their introduction of Hong Kong-Taiwan songs have a strong and lasting impact on the development of social music in the Mainland. For a considerable period of time, the social and cultural environment that is open and suitable for its development has directly brought opportunities to the development of Hong Kong-Taiwan pop music on the mainland and the development of the audiovisual market. At the same time, when such music began to nurture the similar cultural style of "localization" from the soil of musical culture in mainland China, popular songs in Hong Kong and Taiwan, as a new style of music and culture, provided the basis for the development of pop music in mainland China Provided the original template.

\section{Chinese contemporary pop music development}

Ever since the mainland pop music contract system was implemented in 1992, the development of popular music has achieved unprecedented prosperity. The contract signing system has injected a tonic into mainland pop music. But by 1995, with the termination and quit of a large number of new generation singers, the contradiction between singer and producer, singer and record company became increasingly acute, which hindered the healthy development of popular music in one aspect. The major events that have a significant impact in the media and related entertainment and audio-visual publishing industries in this respect are:(1) Because of the appearance fees, Chen Lin and his agent Wang Xiaojing parted ways and Chen Hong also detached himself from "Star Disk" 
Company and established Feihong Company himself. (2) Pan Jindong On May 1995, the performance contract of Qiao Day and Chia Tai International Music Production Center expired, which was convenient for signing with Land Records on May 19, 1995. Because "there is an irrevocable right of renewal" between Pan Jindong and "Chia Tai", Pan Chidong's contact with "the earth" and the preferential conditions that "the earth" gave Pan Jindong, "Chia Tai" are ignorant. Therefore, "Chia Tai" thinks that Pan Jindong's job-hopping is inconsistent with the principle of voluntary, fair, equal compensation and good faith. Ultimately, the parties entered into law on 3 April 1996. The matter finally ended in a mediation. (3) Xie Dong ahead of Beijing Audio and Video Publishing House and the termination, and in 1996 set up East and East Arts Music and Television planning limited liability company. (4) Zheng Jun from Red Star Music Production. (5) the wolf from the "earth" company, joined Huang Xiaomao Beijing popular music studio, fame singer Snow also from the Star company to join them. (6) Gaolin and Guangzhou White Swan signed the contract after the expiration, no longer renew, but the signing of the new constellation of Shanghai. (7) Linyi round from the new era of companies signed letter company. (8) Mao Ning and the new era of company after the expiration of the contract, no longer renew, free from major audio-visual companies did not belong. (9) Zhou Yan chaos from Jin Chunlei company in 1996 to set up their own Simon Culture and Arts Co., Ltd.. L1995, due to singers Liu Haibo, Feng Min without its signing company Star Culture Development Corporation's permission, many violations, for private performances, Star disk decided to remove Liu Haibo in order to safeguard their own interests. Because of Feng Min's attitude sincerely, the company's understanding, to give early termination. And so on. In 1995, when singers switched jobs and the termination of contracts was delayed, some people in 1995 called "termination of the treaty" in pop music.

In response to frequent violations of singers in 1995, the phenomenon of job-hopping, and the resulting contradictions between singers and record labels, record labels and record labels, Guangzhou Pacific Chen Company and Zhejiang Literary Radio Station joined hands with the national music production unit On February 21, 1995, the "95 Chinese Pop Music Experts Seminar" was held in Hangzhou and the "Hangzhou Convention of China Audiovisual Performance Production Jobs" was signed. 'The Convention' has the common interest of protecting the audio-visual entertainment industry in China. 'It stipulates that each party shall sign an effective legal document without the prior consent of the original signatory and shall not sign an audio-visual production agreement with the original signatory artist during the effective contract period Or acting agreement, otherwise the defaulting party shall pay 10 times the liquidated damages as compensation, when contracting parties and contract artists contradictions due to various reasons, other contracting parties may not openly declare when they do not understand the facts ... " The signing of the convention is another major event after China's pop singer signed the singer's contract system, and it is also an indispensable and important step toward the popularization of the pop music system in our country.

\section{Chinese contemporary pop music stage characteristics}

In the music life, people's aesthetic ideas of music, as well as their associated values in life, are not suddenly changed. At the beginning of the reform and opening up, with the opening up of the country, Hong Kong and Taiwan pop music influxed, and people (mainly young people) were rebellious because of their resentment towards the "Cultural Revolution" Popular music or curiosity, or even preferences of different attitudes, is basically a tasting attitude towards Hong Kong and Taiwan music, and does not refuse. Of course, many middle-aged and elderly people are not as keen as young people. However, for the broad masses of the people, even if they do not refuse, it does not mean that their musical concepts have all been changed by popular music in Hong Kong and Taiwan. In this respect, traditional education and traditional aesthetic concepts still play a role in the musical life at that time. From 1979 to 1983, in the music life, the choice of music by the mainland audience basically remained as a traditional lyric song. At that time, the songs expressing the praise of the motherland, longing for a new life and praising the laborers were still the classic authoritative 
words or creative themes that reflected certain ideologies in song creation. These songs are basically followed the tradition of mass lyric songs in the past, there are many with folk style. Orchestra band is still a traditional small orchestra, and occasionally add sand fade, Hawaiian guitar and other color instruments, reflecting a certain era. Singing artists also use more vocal or national singing, and occasionally learn from some "air" singing. Generally do not take the form of hand holding the microphone. The transmission of these songs mainly through radio stations, but do not have the commercial entertainment environment. Therefore, the lyric songs produced in the early 1980s do not have the characteristics of consumer pop music in the entertainment culture in a market economy. It provides people with the entertainment needs, but does not have obvious commercial purposes or commercial practices. In terms of its cultural attributes, it basically belongs to a kind of transitional mass music between mass lyric songs before "Cultural Revolution" and popular music in the mid-1980s. It needs to be mentioned that the music aesthetic taste of the adolescent community in mainland China at this time, apart from the areas adjacent to Hong Kong and Taiwan in the south, still has the influence of traditional education, from the youth group that forms the major audience layer of RTHK's pop music in future. , The traditional lyric songs are still most people like. It is only with the passage of time that the situation has changed as the concept of "youth" has been replaced by "teenagers" who are constantly being replaced by "adolescents" who have grown up in pop music in Hong Kong and Taiwan. At this time, the influence of traditional education weakened and became a disadvantage. Coupled with the laissez-faire and mistakes in education and guidance, when popular music in Hong Kong and Taiwan has cultivated "pop music ears" in adolescents in its sustainable development. It is already too late to talk about the education issues related to popular music in Hong Kong and Taiwan.

With the continuous opening up of China's economy and the vigorous market, due to changes in the mode of consumption in the social and cultural life, the demand and consumption of pop music have also gradually become commercial and cultural in supply and demand. In addition to the traditional media publicity, in fact, Hong Kong and Taiwan pop music, as a typical representative of popular music at this time, has become the preferred target of commercial music and entertainment. The pop music market is active; a cultural atmosphere conducive to its own development has been formed, while participants have more choices in entertainment. While the official media are still broadcasting popular lyric songs of the mainland like "The Moon on the 15th" and "Fountain in the Frontier Pure and Pure," the numerous music cafes, dance halls and even the streets in the market atmosphere Various commercial shops, stations and other places with the most floating population are endlessly broadcasting popular songs of Hong Kong and Taiwan. The appearance of this phenomenon is often earlier than we estimated. At the time of the press, there was such a record: "At present, Guangzhou has imported 200,000 sound recorders, ... it can hear the light music and popular songs of foreign countries, Hong Kong and Maucao everywhere, and some have also set up street cafes and ticket sales. Tea to listen to music; copy imported original tapes ... ... and even Beijing streets also sell offset booklet `Hong Kong singer xxx song set '... ..."

With tape recorders becoming the most fashionable home appliances, cassette tapes have begun to popularize mainland China since 1979. Due to the dexterity and convenience of application effects, this music carrier became a collection of Chinese music listeners in a very short time and became the most popular music product. According to the comprehensive statistics on the relevant materials, "the production volume of the national commodity recording cassette was 6 million in 1982, 18 million in 1982, 40 million in 1984, 70 million in 1985 and 4 million in 1956 In 1987, when it came to the peak of commodity cartons, the annual production volume was 120 million boxes .... Of the music variety cassettes, $8 \% 5$ is popular music, including the popularization of RTHK pop music Version, Hong Kong and Taiwan version of the popular music simulation, the mainland's own popular music, traditional Chinese folk songs, opera singing 'modified' pop music, European and American pop music, dance music. " This means that the advent of pop music cassettes and tape recorders provides an immediate opportunity for the development of pop culture. Pop music is popular pop music, the first step in commercialization. Since most of these boxes in the market are actually popular music in Hong Kong and Taiwan, such individualized and 
family-oriented ways of enjoying music mean that public music has a completely autonomous system outside of such media as television and radio Choice, which in fact means that the influence of the mainstream ideology weakened. At the same time, it also formed one of the largest supply and demand relationships with the audio-video publishing and distribution market.

\section{Conclusion}

Although contemporary Chinese pop music is a new phenomenon in contemporary Chinese music life, its development has been rather rapid and has a broad mass base, which has become an important part of contemporary Chinese music life. However, due to various reasons, the research on pop music has not been carried out in depth. For the definition of the concept of popular music, the judgment of pop cultural attributes, the influence of popular music on education and the social function of pop music, a great deal of important problems have not been achieved. On the pop music issue, there are usually many comments, many random opinions, lots of discussion, and sharp and contradictory opinions on the evaluation. For any kind of study of historical and cultural phenomena, historical research should be the starting point of all research.

\section{Acknowledgements}

Fund Project: 2017 National Art Fund Project (2017-A-04- (050) -0564)

Shaanxi Province in 2017 military and civilian integration research fund project (17JMR06)

Weinan Teachers College of Education Science International Cooperation Project (17GJHZ10)

\section{References}

[1] Zhu Xiaodan in the first Guangzhou pop music seminar speech [J]. People's music. 1994 (07)

[2] Purple Yan. State Copyright Bureau announced - China Music Copyright Association was established [J]. Music World. 1993 (07)

[3] Wenzhi. The gain and loss - Reflections on karaoke [J]. People's Music 1992 (07)

[4] Bai Fan. Breakthrough and Transcendence: An Urgent Problem Facing Popular Music - A Review of the National Popular Music Symposium [J]. Chinese Musicology, 1988 (02)

[5] Si Jianjun. Audio-video publishing work needs rectification [J]. People's Music. 1988 (04)

[6] Cheng Yun. Chinese contemporary popular music video [J]. People's Music. 1988 (02) 